\title{
Influence of Near-surface Stratigraphy on Coastal Landslides at Sleeping Bear Dunes National Lakeshore, Lake Michigan, USA
}

\author{
Walter A. Barnhardt $\dagger$, Bruce E. Jaffe $\ddagger$, Robert E. Kayen $\ddagger$, and Guy R. Cochrane $\ddagger$
}

$\dagger$ U.S. Geological Survey 384 Woods Hole Road Woods Hole, MA 02543, USA

\author{
$\ddagger$ U.S. Geological Survey \\ 345 Middlefield Road \\ Mail Stop 999 \\ Menlo Park, CA 94025, USA
}

\begin{abstract}
BARNHARDT, W.A.; JAFFE, B.E.; KAYEN, R.E., and COCHRANE, G.R., 2004. Influence of near-surface stratigraphy on coastal landslides at Sleeping Bear Dunes National Lakeshore, Lake Michigan, USA. Journal of Coastal Research, 20(2), 510-522. West Palm Beach (Florida), ISSN 0749-0208.

Lake-level change and landslides are primary controls on the development of coastal environments along the coast of northeastern Lake Michigan. The late Quaternary geology of Sleeping Bear Dunes National Lakeshore was examined with high-resolution seismic reflection profiles, ground-penetrating radar (GPR), and boreholes. Based on sequencestratigraphic principles, this study recognizes ten stratigraphic units and three major unconformities that were formed by late Pleistocene glaciation and postglacial lake-level changes. Locally high sediment supply, and reworking by two regressions and a transgression have produced a complex stratigraphy that is prone to episodic failure. In 1995, a large landslide deposited approximately 1 million $\mathrm{m}^{3}$ of sediment on the lake floor. The highly deformed landslide deposits, up to $18 \mathrm{~m}$ thick, extend 3-4 km offshore and unconformably overlie well-stratified glacial and lacustrine sediment. The landslide-prone bluff is underlain by channel-fill deposits that are oriented nearly perpendicular to the shoreline. The paleochannels are at least $10 \mathrm{~m}$ deep and $400 \mathrm{~m}$ wide and probably represent stream incision during a lake-level lowstand about $10.3 \mathrm{ka}$ B.P. The channels filled with sediment during the subsequent transgression and lake-level highstand, which climaxed about $4.5 \mathrm{ka}$ B.P. As lake level fell from the highstand, the formation of beach ridges and sand dunes sealed off the channel and isolated a small inland lake (Glen Lake), which lies $5 \mathrm{~m}$ above the level of Lake Michigan and may be a source of piped groundwater. Our hypothesis is that the paleochannels act as conduits for pore water flow, and thereby locally reduce soil strength and promote slope failure.
\end{abstract}

ADDITIONAL INDEX WORDS: Lake-level change, sequence stratigraphy, paleochannel, groundwater, seismic reflection, ground-penetrating radar.

\section{INTRODUCTION}

Thick deposits of late Quaternary sediment form bluffs up to $30 \mathrm{~m}$ high at Sleeping Bear Dunes National Lakeshore (SBDNL), located on the northeastern coast of Lake Michigan (Figure 1). Coastal bluffs in the region typically consist of sandy dune deposits that overlie glacial and lacustrine sediment, and have developed in response to Holocene lake-level changes (Arbogast and Loope, 1999). The Lake Michigan coast has experienced several transgressive and regressive events since the retreat of late Wisconsinan ice sheet, with lake levels fluctuating from about $18 \mathrm{~m}$ higher and $80 \mathrm{~m}$ lower than the present level (HANsel et al., 1985; Colman et $a l .$, 1994). Decreases in lake level have exposed shallow areas of the lake bottom, and have favored the formation of beach ridges and sandy dune deposits (THOMPson and BAEDKE, 1997). Increases in lake level have caused shoreline transgression and erosion of dunes, often accompanied by landslides (HANDS, 1979).

Large landslides have occurred without warning at SBDNL in 1914, 1971, and 1995. All three landslides involved the same 500-m long stretch of coast and, in each case, removed

01005 received 16 July 2001; accepted in revision 2 November 2002. a section of beach and bluff extending up to $60 \mathrm{~m}$ inland from the shoreline. Although there are $56 \mathrm{~km}$ of lakeshore in SBDNL, only this single location has experienced multiple, deep-seated failures. One hypothesis for the high frequency of landslides was erosional undercutting by waves, but bathymetric surveys have indicated steady accumulation, not erosion of sediment in the offshore area adjacent to the bluff (NOAA, 1971). This study explores a second hypothesis that geologic structure is the primary control on the highly localized bluff instability. If this hypothesis is correct, the landslide-prone section of bluff must exhibit anomalous characteristics not present elsewhere in SBDNL. The hydrogeological properties of sediment in the landslide zone may locally reduce sediment strength and, thus, increase potential for landslides. The main objectives of this paper are to examine: 1) the stratigraphic record of late Quaternary lake-level change, and 2) the non-uniform geologic conditions that may control the location and frequency of landslides.

\section{PHYSICAL SETTING}

Sleeping Bear Point, the primary study area, is a coastal headland that forms the western margin of a small embayment in northeast Lake Michigan (Figure 2). Eroding bluffs 

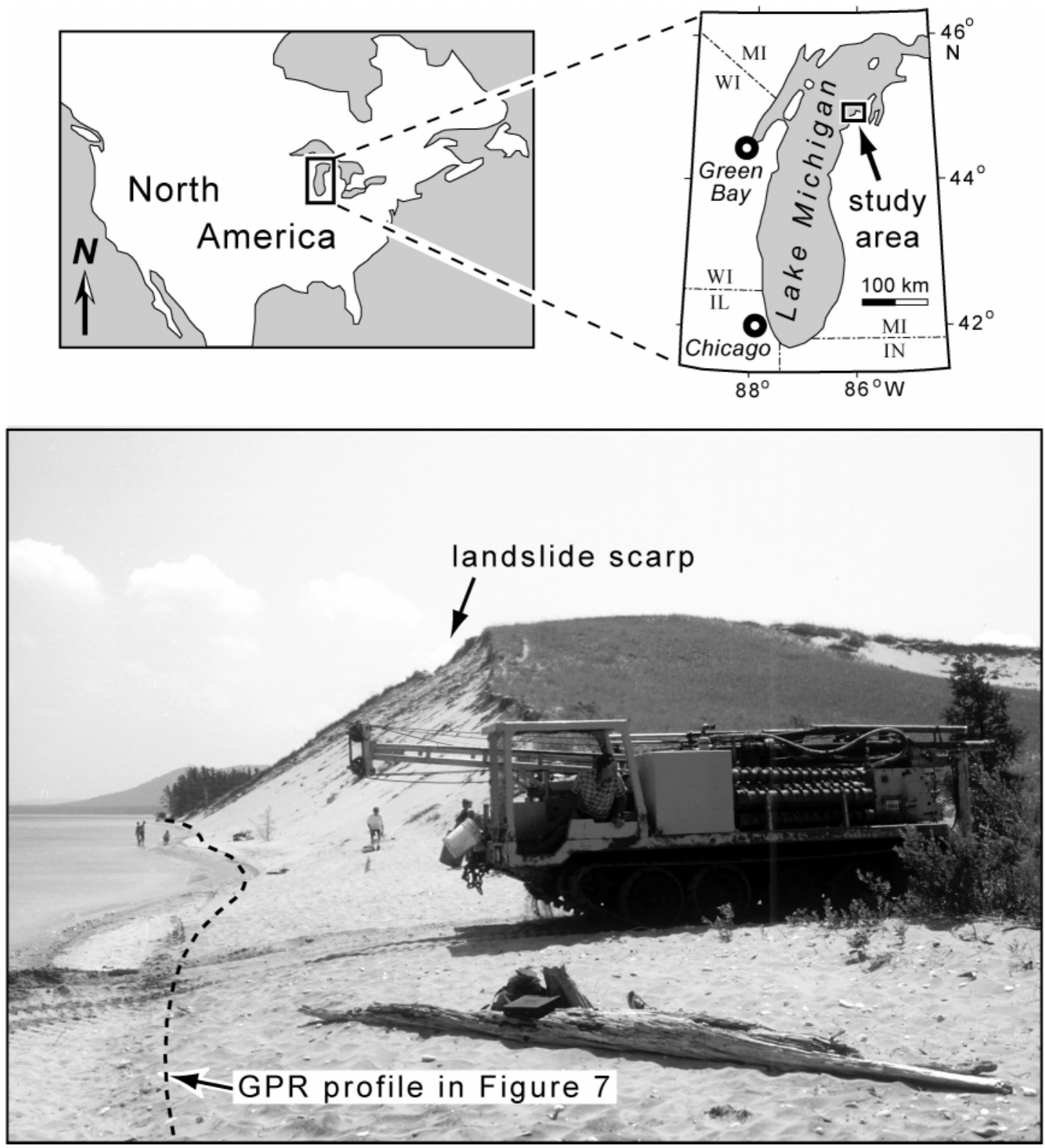

Figure 1. Location map of study area on northeast coast of Lake Michigan (top), and photograph of beach and failed bluff at Sleeping Bear Point (bottom). View is towards the southeast. Dashed line indicates location of GPR profile in Figure 7. Two boreholes are located at the rear (right) of the drill rig.

of glacial deposits occur on the exposed part (north and northwest) of the headland and supply sand downwind (south) to a $10 \mathrm{~km}^{2}$ field of large sand dunes. The crest of the highest dune is about $136 \mathrm{~m}$ above lake level, but the dunes are not that thick, rather they are "perched dunes" that rest on a platform of glacial deposits (DorR and EschmanN, 1970, p. 203). Wind-blown sand has buried trees on the inland side of the dunes as they actively migrate in the direction of Glen Lake, a small inland basin. Coastal geomorphic features also indicate the transport of abundant sand from Sleeping Bear Point to the east, where a strand plain of beach ridges sep- arates Lake Michigan from Glen Lake. The beach ridges are typically $2-3 \mathrm{~m}$ high relative to the intervening swales. The outlet stream that drains Glen Lake meanders through the beach ridges and discharges into Lake Michigan, which is about $5 \mathrm{~m}$ lower in elevation. At higher lake levels, Glen Lake was probably connected to Lake Michigan.

The Lake Michigan basin is a large, generally smoothfloored depression formed, at least in part, by multiple Pleistocene glaciations. In northeastern Lake Michigan, however, the lake floor is characterized by a distinct series of elongate, north-south trending valleys and ridges with local bathymet- 


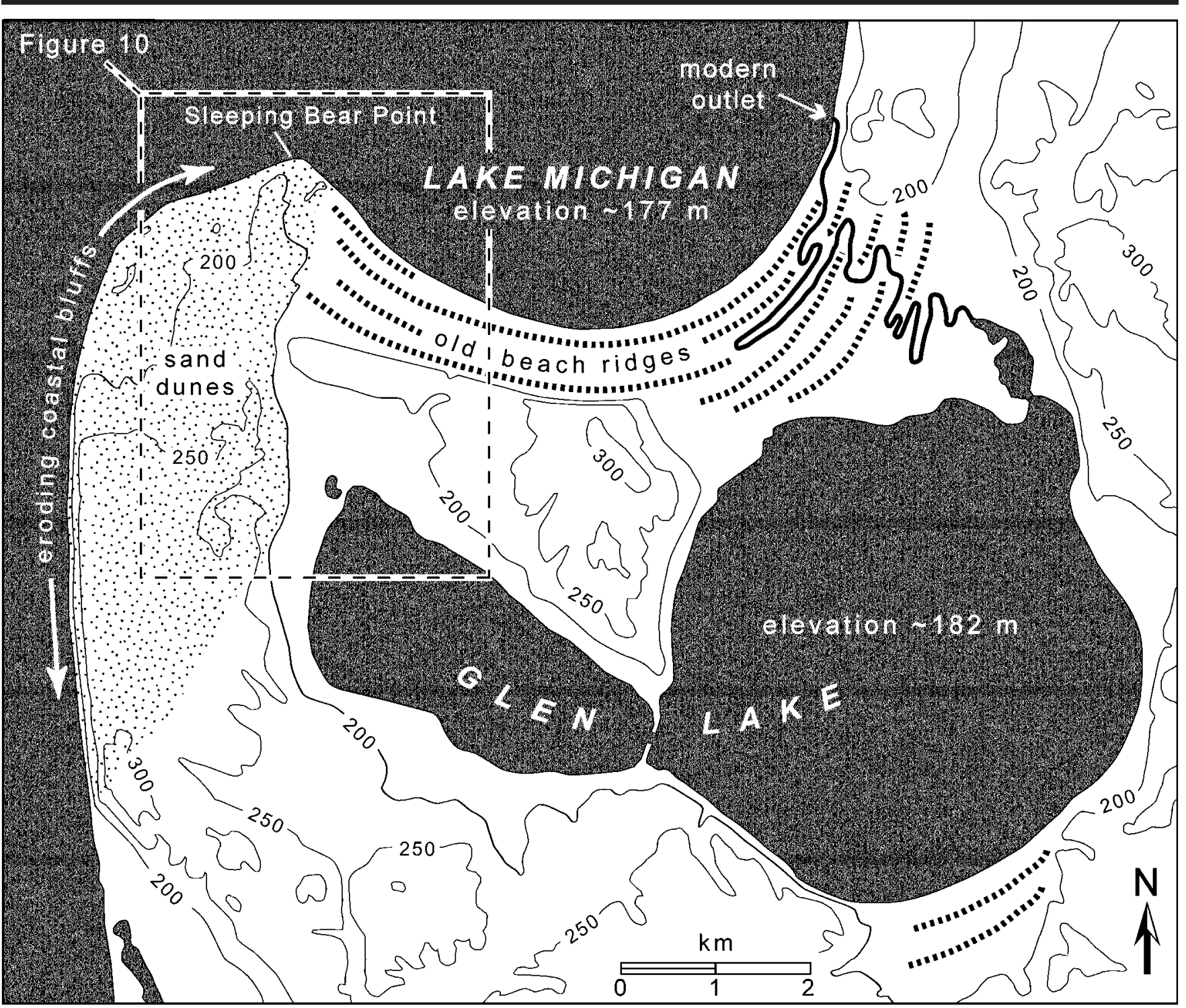

Figure 2. Physiographic map of Sleeping Bear Dunes National Lakeshore and vicinity. The 200-m contour marks the approximate extent of glacial deposits exposed on uplands. Sediment below that elevation (light gray shading) generally has been reworked during lake-level highstands. Location and geometry of beach ridges are schematic.

ric relief of over $180 \mathrm{~m}$. The valleys may represent erosion by subglacial meltwater (G. LARSON, personal communication, 1998), a process that also may have formed the Finger Lakes in New York (Mullins and HinCHEY, 1989). A discontinuous veneer of glacigenic sediment, including till, outwash, and glacial-lacustrine deposits of sand and clay, overlies Paleozoic bedrock in the Lake Michigan region (Hough, 1958).

Water levels in Lake Michigan fluctuated widely after the retreat of the Laurentide Ice Sheet (Figure 3A), largely due to differential isostatic uplift, and the shifting and downcutting of outlets (HANSEL et al., 1985). Numerous workers have inferred lake-level highstands from ancient wave-cut platforms and relict shorelines (HANsEL et al., 1985; HANSEL and Mickelson, 1988; Larsen, 1985; Thompson and BaEdKe,
1997). Lake level in southern Lake Michigan fell to a minimum of $80 \mathrm{~m}$ below present during the Chippewa phase that lasted from about 10,300 to $5,500 \mathrm{C}^{14}$ years B.P. (HougH, 1958; Colman et al., 1994). The lowering of base level caused deep incision by rivers, which later filled with sediment and formed paleochannel deposits in southern Lake Michigan (Foster and Colman, 1991). The study area at Sleeping Bear Point probably experienced a similar episode of relative lake-level fall and incision, although isostatic rebound in northern parts of the lake basin probably altered the timing and magnitude of the lowstand. After the lowstand, lake level rose to approximately $7 \mathrm{~m}$ higher than present during the Nipissing phase about $4,700 \mathrm{C}^{14}$ years B.P., when distinct shoreline features formed in the vicinity of SBDNL and 

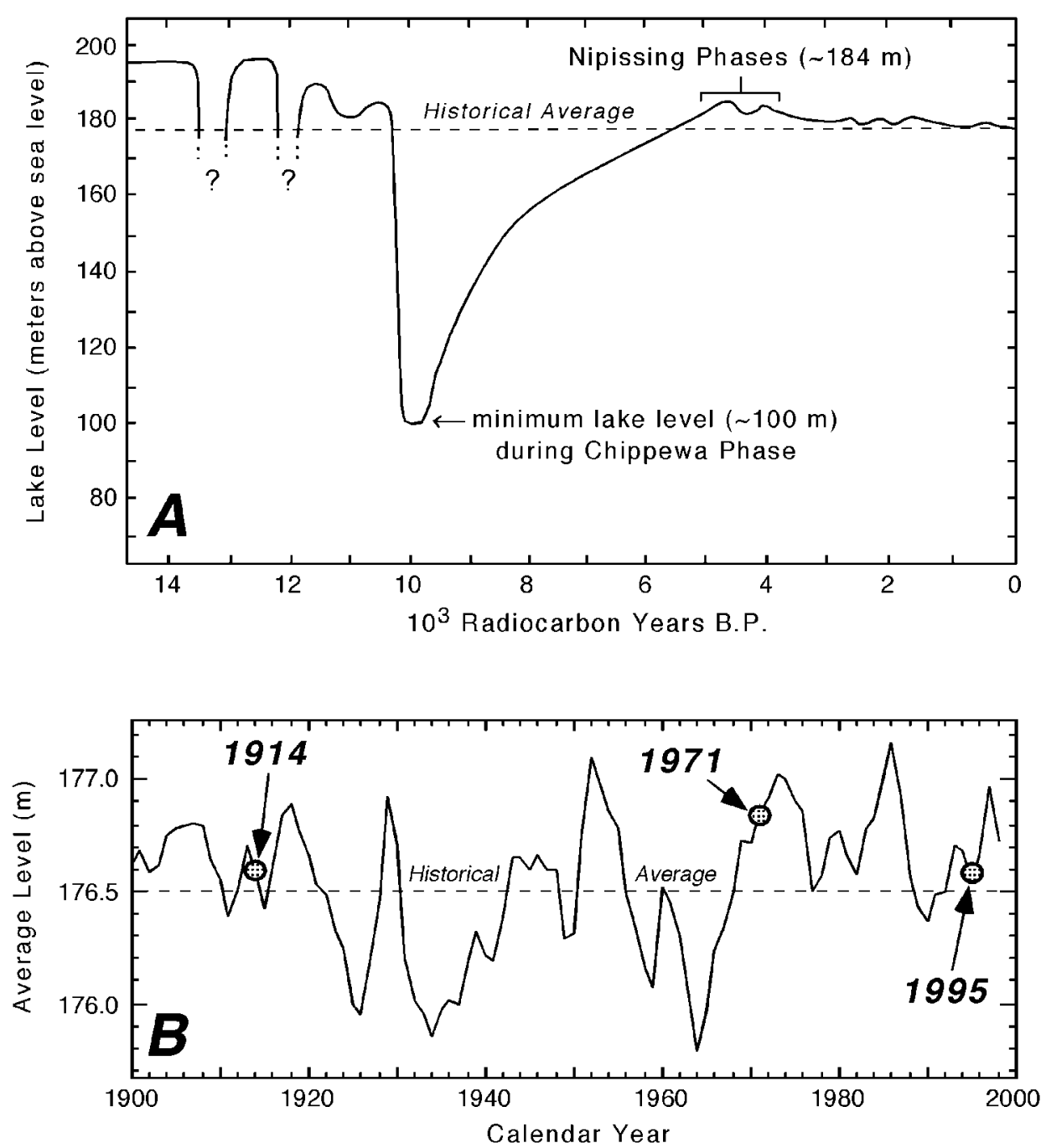

Figure 3. (A) Relative lake-level curve for southern Lake Michigan over past 14,500 years (after HANSEL et al., 1985; CoLMAN et al., 1990; CHRZASTOWSKI and Thompson, 1992). This curve makes no provision for isostatic rebound and does not have direct application to the study area, but is presented as a general reference. (B) Historical record of water levels in Lake Michigan from 1900-1998 and the occurrence of large landslides at Sleeping Bear Point in 1914, 1971, and 1995. Dashed line indicates $176.5 \mathrm{~m}$ above sea level, the 99-year average elevation of the lake. The $1900-1990$ data are from National Oceanic and Atmospheric Administration (http://www.glerl.noaa.gov/data/mnth-hydro.html); the 1991-1998 data are from the U.S. Army Corps of Engineers (http://www.lre.usace.army.mil/levels/hlevmh.html).

throughout the Great Lakes region (HANsEL et al., 1985). Differences in isostatic rebound were less pronounced in the late Holocene, as shown by the similar timings of high and low lake-levels at five sites around the lake basin (BAEDKE and ThOMPson, 2000). Less extreme fluctuations in the level of Lake Michigan, probably related to climatic factors, have controlled the development of beach-ridge complexes in several locations (DotT and Mickelson, 1995; LiCHTER, 1995; THOMPson and BAEDKE, 1997).

Short-term (1-10 year time scale) changes of 1-2 $\mathrm{m}$ in magnitude have also occurred since the $1860 \mathrm{~s}$, with high lake levels causing periods of severe coastal erosion (FRASER et $a l .$, 1990). The three large landslides at Sleeping Bear Point all occurred during times of above average lake levels (Figure $3 \mathrm{~B})$, and are limited to the Winter and early Spring months.
Winter is typically very cold, with mean air temperatures of approximately $-6^{\circ} \mathrm{C}$ in January, and is dominated by Arctic air masses that arrive out of the northwest (SommERs, 1977). Mild air masses from the south occasionally generate thaws during winter months. Moisture derived from Lake Michigan creates heavy snowfall on the downwind (southeast), or lee sides of the lake, including an average of 200-250 cm/year in the SBDNL area (Sommers, 1977). Wave conditions are more energetic during the winter months, when strong winds can generate significant wave heights of 5-6 $\mathrm{m}$ in northern Lake Michigan (National Buoy Data Center, 1999).

\section{METHODS}

Approximately $26 \mathrm{~km}$ of single-channel seismic reflection profiles were collected with an Ocean Research Equipment 
(ORE) Geopulse boomer system. The analog system was run at frequencies centered around $1.5 \mathrm{kHz}$ and was operated at 400 joules power and $1 / 2$ second sweep. The acoustic signals typically penetrated the lake floor to subbottom depths of 30 to $60 \mathrm{~m}$. Conversions from travel time to depth were based on a velocity of $1500 \mathrm{~m} / \mathrm{s}$ that was assumed through both water and sediment. Navigation was based on GPS and tracklines were plotted using a geographic information system. Depths were recorded by precision fathometer.

Approximately $2.5 \mathrm{~km}$ of digital GPR reflection profiles were collected along the beaches and dunes at Sleeping Bear Point, using a pulseEKKO100 system with a $1000 \mathrm{~V}$ transmitter. Some profiles were surveyed twice with antennas of different frequencies. Whereas the $100 \mathrm{MHz}$ antennas provided a finer scale of resolution, the lower frequency $50 \mathrm{MHz}$ antennas gave greater depth of penetration. Image quality was optimized in the field by stacking 32 shots at each point along a profile and by subsequent processing of the digital data. Topography was surveyed with differential GPS and used to correct the profiles with vertical accuracy of $\pm 5 \mathrm{~cm}$.

Seismic reflection and GPR are complimentary techniques that provide high-resolution, continuous imagery of the subsurface. Both systems measure travel time and amplitude of reflected signals, and data acquisition is rapid and non-destructive. Different physical principles underlie the two systems, however, and environmental conditions restrict their application. Seismic reflection, for example, is useful offshore because it has an acoustic source, but is limited to areas of relatively deep water due to problems with multiple returns obscuring the data. In contrast, GPR is most useful onshore, or in shallow, freshwater lakes and rivers (BERES and HAENI, 1991), because water rapidly attenuates electromagnetic energy. Under ideal conditions (i.e., dry sand and gravel), maximum exploration depth with $50 \mathrm{MHz}$ antennas is approximately $47 \mathrm{~m}$ (SмIтH and JoL, 1995). Resolution, or the ability to detect objects of a given size, is strongly related to operating frequency in both acoustic- and radar-based systems. Higher frequency signals can resolve relatively smaller objects than lower frequency signals, but are attenuated more rapidly, thus limiting the depth of penetration. In both GPR and seismic reflection, depth of penetration is inversely related to resolution.

Crosshole GPR surveys were also performed adjacent to the landslide zone. The acquisition methods and processing requirements of crosshole surveys are very different from reflection surveys. In a crosshole survey, transmitter and receiver antennas are lowered down two boreholes and GPR signals are transmitted between them. The distance that separates the antennas is known, and one-way travel time is precisely measured to yield velocity. These direct measurements of velocity were used to convert travel time on GPR reflection profiles to depth.

Seven boreholes were drilled at two sites adjacent to the landslide zone. Depths of the holes ranged from 18-38 m below the ground. Subsurface sediment samples were collected and visually described for texture. Each borehole was cased with PVC pipe, screened at different depths to allow free exchange of groundwater, and pumped to condition the wells. Piezometers were placed in four of the boreholes to monitor pore pressure within the bluff. Data from the instruments are transmitted via satellite for real-time analysis, and have been monitored since 1997 to provide warning of potential increases in slide hazard. To date, no anomalous variations have been recorded, nor have additional landslides occurred.

\section{OFFSHORE STRATIGRAPHY}

A closely-spaced network of seismic reflection profiles was collected to examine submerged areas adjacent to Sleeping Bear Point, and to determine the general extent and thickness of landslide deposits on the lake floor (Figure 4A). In our analysis of the seismic-reflection data, we recognize five stratigraphic units using the approach of VAIL et al. (1977) and PosAmentier and VAIL (1988). The seismic-stratigraphic units are defined by: 1) morphology and intensity of reflections at bounding surfaces, 2) intensity and coherence of internal reflections, 3) geometry or shape of an assemblage of similar reflections, and 4) stratigraphic setting or occurrence. For consistency, we generally retain the nomenclature of Colman et al. (1994), which was, in turn, based on the formation names of LiNEBACK et al. (1970). Paleozoic bedrock, which underlies much of the region, was not observed in this study. No new chronological data was collected, and our stratigraphic interpretations rely on previous research in the region, especially on subaqueous studies by FOSTER and COLMAN (1991, 1992) and CoLMAN et al. (1994).

Unit Qw (Pleistocene Wedron Formation; Lineback et al., 1970 ) is characterized by a sharp, high-intensity reflection from an irregular upper surface and a mound-shaped geometry with over $30 \mathrm{~m}$ of relief (Figure 5). Internal reflections are scattered and incoherent. Hummocky deposits in the Gulf of Maine exhibit a similar acoustic signature and also have been interpreted as ridges of till, or moraines (KNEBEL and SCANLON, 1985). Unit Qw, when present, always occurs at the base of the section and is interpreted as till of Pleistocene age. Till deposits in this study are undifferentiated, although Foster and Colman (1991) described five different till members in southern Lake Michigan.

Unit Qe (Pleistocene Equality Formation; LINEBACK et al., 1970) exhibits a upper surface with relatively low reflectivity and up to $5 \mathrm{~m}$ of relief (Figure 5). Internal reflections are poorly defined and generally mimic the irregular shape of the upper surface. Core samples of unit $\mathrm{Qe}$ in southern Lake Michigan contained interbedded mud, sand, and pebbles (Colman et al., 1990). This study observed Unit Qe in only one location, where it terminated laterally against unit $\mathrm{Qw}$. Unit $\mathrm{Qe}$ is interpreted as glacial outwash deposits of Pleistocene age.

Unit Qll exhibits a smooth, moderately reflective upper surface that gently slopes down towards deeper parts of the lake basin (Figure 5). The numerous internal reflections of unit Qll are well-defined and laterally continuous. Prominent sets of coherent, parallel reflections are traceable throughout the study area. The well stratified deposits are typically 10$20 \mathrm{~m}$ thick and overlie both unit Qw and unit Qe, when present. Core samples of unit Qll in southern Lake Michigan consist of very fine-grained, reddish clay with silt rhythmites (Colman et al., 1990). Foster and Colman (1991) infor- 

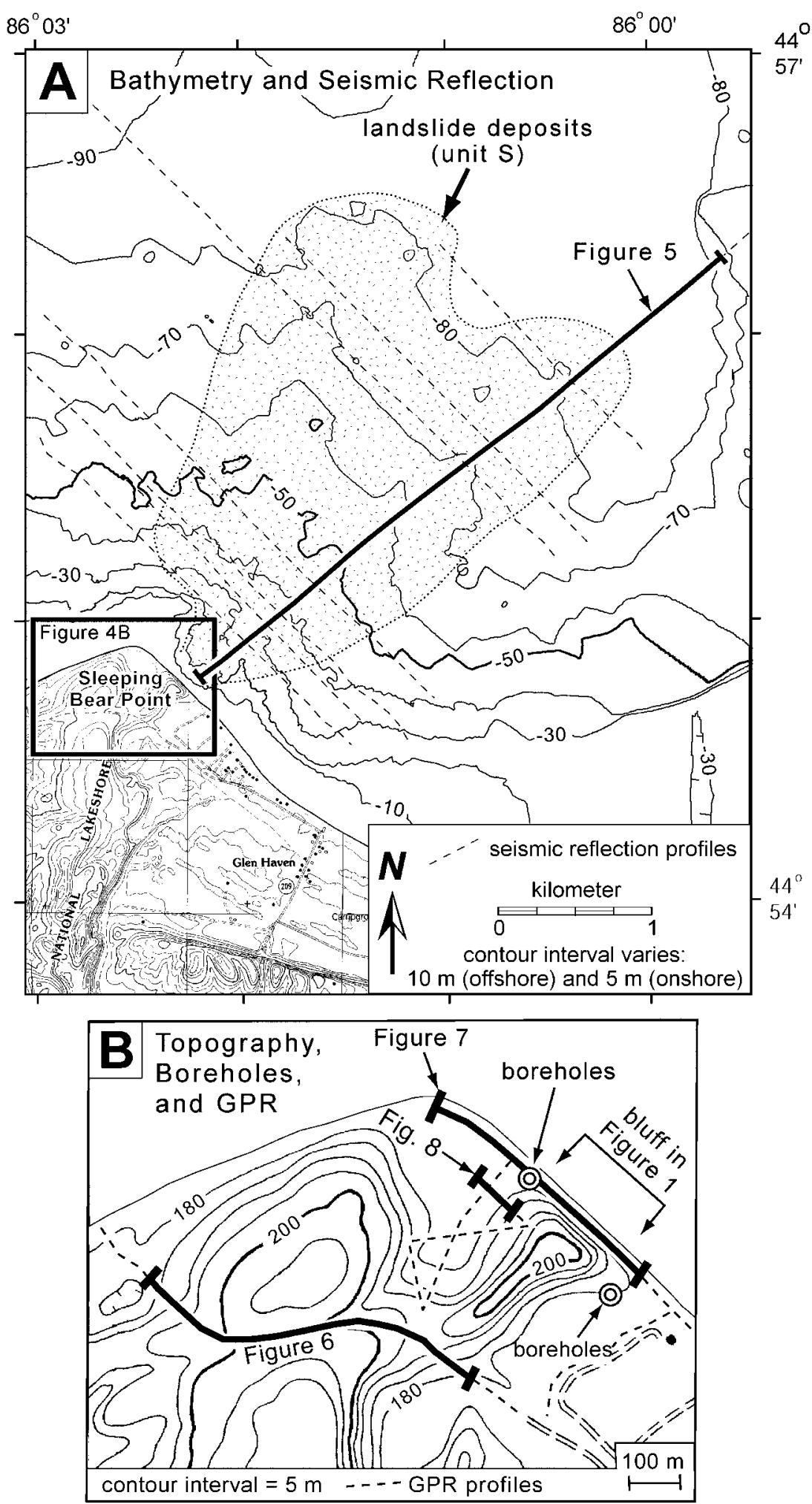

Figure 4. (A) Map of study area showing lake-floor bathymetry and locations of seismic reflection profiles. Stippled area indicates approximate extent of landslide deposits. (B) Inset map of Sleeping Bear Point (boxed area in A) showing topographic contours, GPR profiles and boreholes. Note: bathymetric contours have a 10-m interval and are relative to lake level (Michigan-Huron Low Water Datum); topographic contours have a 5-m interval and are relative to sea level (NGVD-29). Bathymetry is from NOAA (1971) and the onshore base map is Glen Haven, Michigan 7.5' quadrangle (USGS, 1983). 


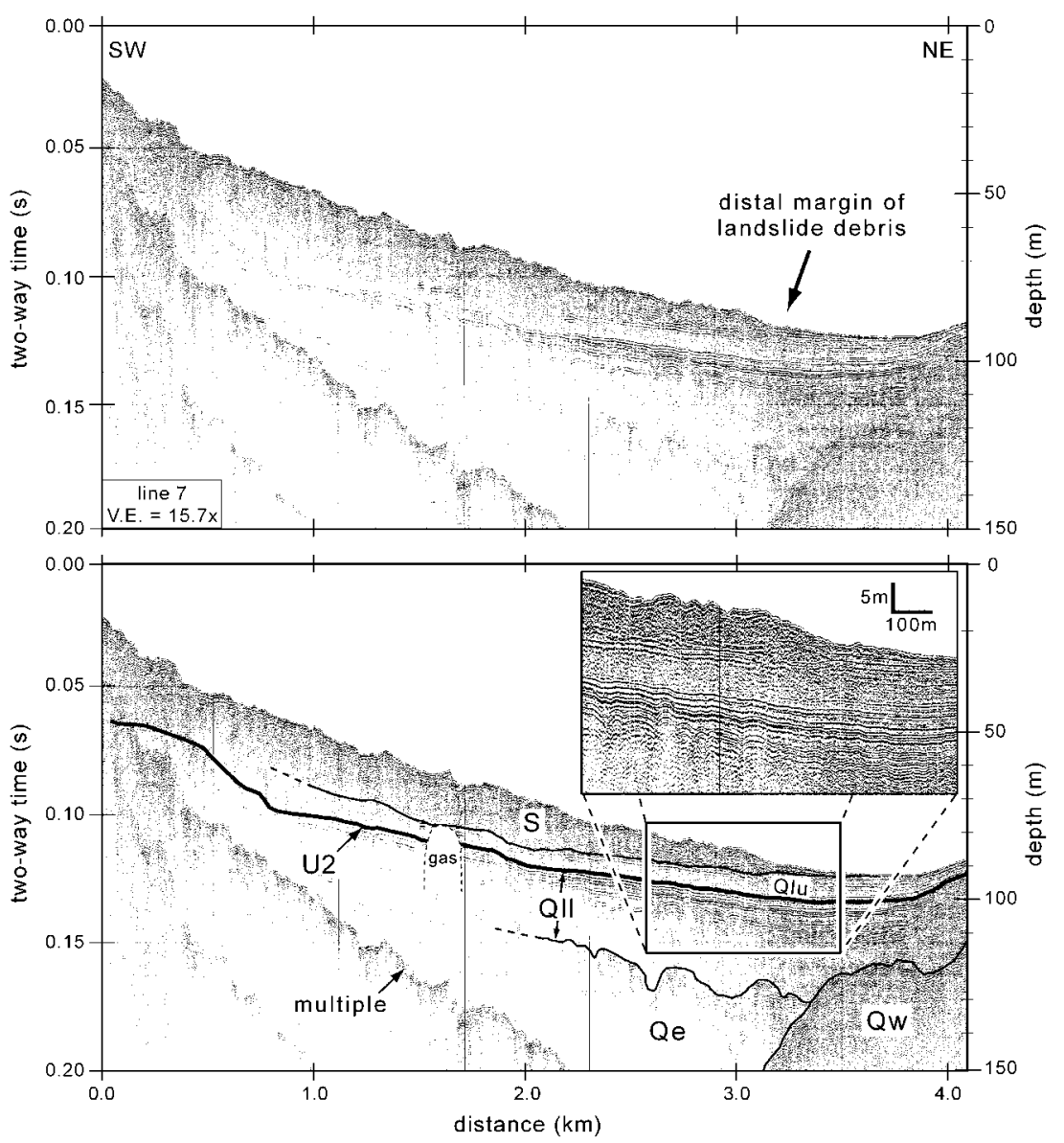

Figure 5. Seismic reflection profile across landslide deposits, oriented perpendicular to shoreline at Sleeping Bear Point. See text for description of units. Location indicated in Figure 4A.

mally designated Unit Q1l as the "lower Lake Michigan Formation (p. 10)" and inferred deposition in an ice-distal, glaciolacustrine environment.

Unit Qlu is a sheet-like layer with low amplitude but continuous, parallel internal reflections (Figure 5). Unit Qlu unconformably overlies unit Qll and crops out on the lake floor in many locations. FOSTER and COLMAN (1991) informally designated unit Qlu as the "upper Lake Michigan Formation (p. 10)" or postglacial seismic sequence, which consists of Holocene lacustrine sediment. Cores collected by CoLMAN et al. (1990) contained brown silty clay in deeper basins that graded into sand in shallow, nearshore areas.

Unit $\mathbf{S}$ is a new, previously undescribed unit that exhibits a highly reflective, irregular upper surface with local relief of 3-5 m (Figure 5). Internal reflections are generally chaotic but include locally continuous packages of reflections that are flat-lying to steeply sloping. Unit $\mathrm{S}$ is a wedge-shaped deposit up to $2.5 \mathrm{~km}$ wide and $18 \mathrm{~m}$ thick that pinches out approximately $3-4 \mathrm{~km}$ offshore. The complexly deformed deposits cover a total area of approximately $20 \mathrm{~km}^{2}$ on the lake floor adjacent to Sleeping Bear Point (Figure 4A). Unit $\mathrm{S}$ is always the uppermost unit, when present, and is interpreted as land- slide debris. The total volume of the most recent deposit (i.e., the 1995 landslide) is estimated at one million cubic meters. No cores or grab samples were collected, but video observations confirmed that the landslide deposit consists of sandy sediment mixed with numerous trees and other debris.

\section{ONSHORE STRATIGRAPHY}

Sediment deposits in onshore parts of the study area consist of uniformly quartz-rich, well-sorted, medium to coarse sand that was sampled in boreholes as deep as $38 \mathrm{~m}$ below the ground surface. No clayey sediment was observed, but clay-rich layers have been observed in bluffs elsewhere along the coast and probably play an important role in local groundwater hydrology. GPR surveys show, however, that the stratigraphy is more complex than indicated by the borehole data alone. Strong, continuous reflections were recorded as deep as $25 \mathrm{~m}$ below the ground surface, providing high resolution images of bluff stratigraphy. Using the same sequence-stratigraphic approach as described for offshore areas, we defined five stratigraphic units, or radar facies, in the onshore area.

Unit A exhibits an irregular, highly reflective upper surface 


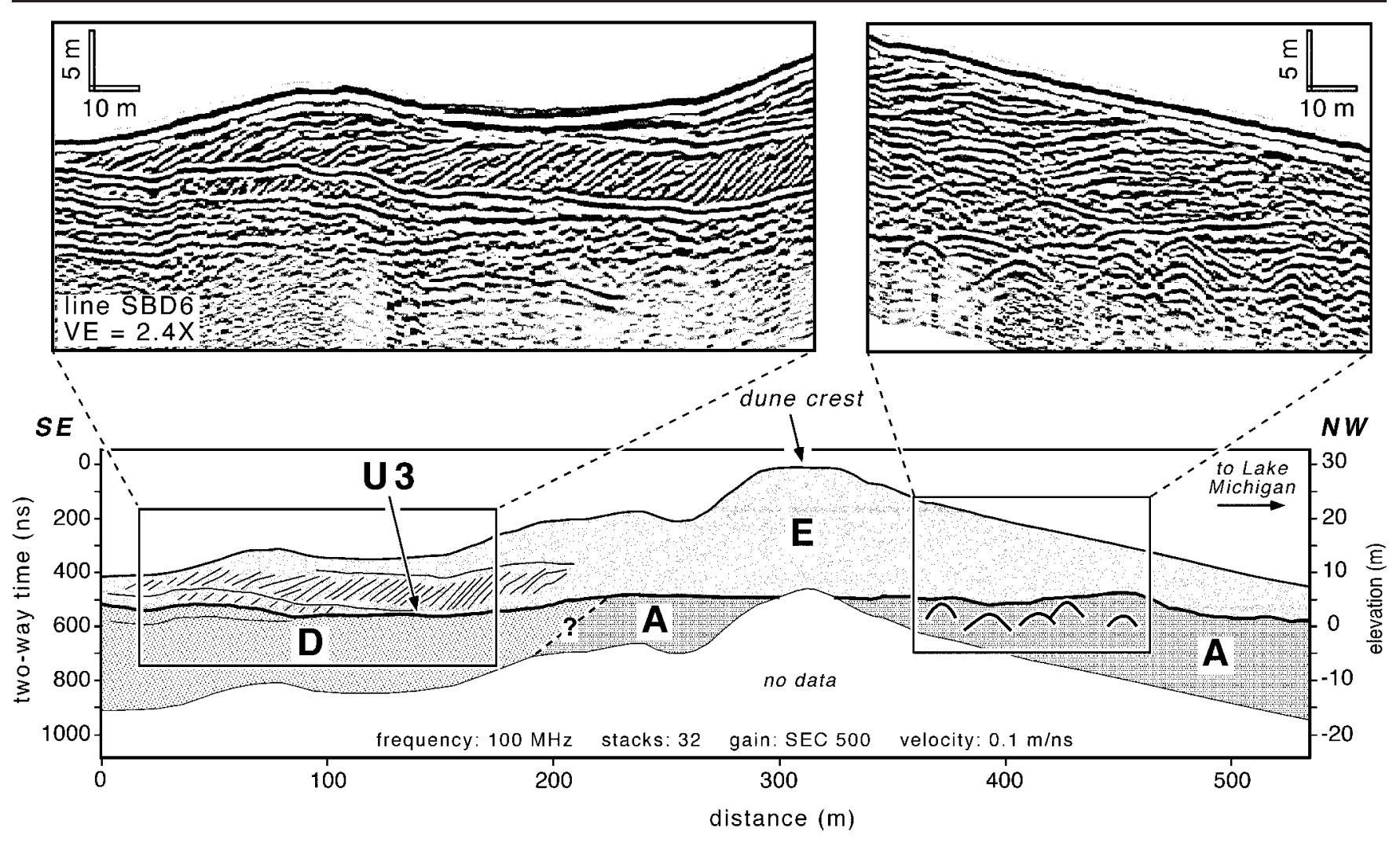

Figure 6. Interpreted GPR profile across large dune at Sleeping Bear Point, with insets of original data. See text for description of units. Location indicated in Figure 4B.

with up to $5 \mathrm{~m}$ of local relief (Figure 6). Internal reflections are heterogeneous, and range from laterally coherent, subhorizontal stratification to incoherent, poorly stratified deposits with large-scale hyperbolic reflections. The latter are created when the diverging, cone-shaped beam of GPR signals encounter, for example, a boulder in a sandy matrix. Energy is not only reflected in the near-vertical plane, but is also reflected as the GPR system approaches, passes over, and moves away from such a point-source reflector, thus creating a reflection that takes the shape of an upside " $U$ ", or hyperbola. A buried tree or stump would also create similar reflections. Unit A, when present, is always the lowermost unit and is generally buried beneath large sand dunes. Locally, it crops out on the surface, where cobbles and boulders were observed. We interpret unit A to represent glacial sediment of Pleistocene age, including both outwash (well stratified) and till (hyperbolic reflections).

Unit B exhibits an irregular upper surface with relief that locally exceeds $10 \mathrm{~m}$ and is characterized by a high-amplitude reflection (Figure 7). Unit B always occurs at the base of the section, but has not been observed in direct contact with unit A. The total thickness is unknown, and it has not been directly sampled. Closely spaced, clinoform reflections are abundant and have an apparent dip (i.e., dip along our profile) of 12-16 degrees down to the southeast. The true dip may be steeper. We interpret the dipping reflections of unit
B as a distal facies on an outwash fan-delta complex of a proglacial lake sequence. Alternatively, Unit B could represent the lakeward-dipping beds of a prograding spit that formed prior to the Chippewa phase lowstand, or dune deposits that subaerially formed when lake level was low. The sediment supply is inferred to come from the northwest around Sleeping Bear Point, like the modern system of littoral drift. The bedding is probably too irregular for an eolian deposit, however, and scattered hyperbolic reflections in this unit suggest the presence of isolated pebbles or boulders.

Unit $\mathbf{C}$ exhibits a channel-shape geometry and is cut into underlying unit A (Figures 7 and 8). It is limited in lateral extent, and was observed only in areas adjacent to the landslide zone. The channel-fill deposits are up to $400 \mathrm{~m}$ wide and vary in thickness from 3 to at least $10 \mathrm{~m}$. The total thickness is not known because no GPR reflections were recorded in the center, or thalweg, of the channel. A smaller channel, about $50 \mathrm{~m}$ wide and $6 \mathrm{~m}$ thick, occurs stacked beneath the margin of the main channel. Unit $\mathrm{C}$ has well defined, wavy internal stratification that mimics the shape of the basal contact. The channel-fill sediment of unit $\mathrm{C}$ was sampled by a tractor-mounted auger and consisted of clean, well sorted, medium to coarse sand with minor gravel.

Unit D unconformably overlies both unit B and unit C, and was observed only beneath beaches in the vicinity of Sleeping Bear Point. It exhibits a sheet-like geometry and varies in 

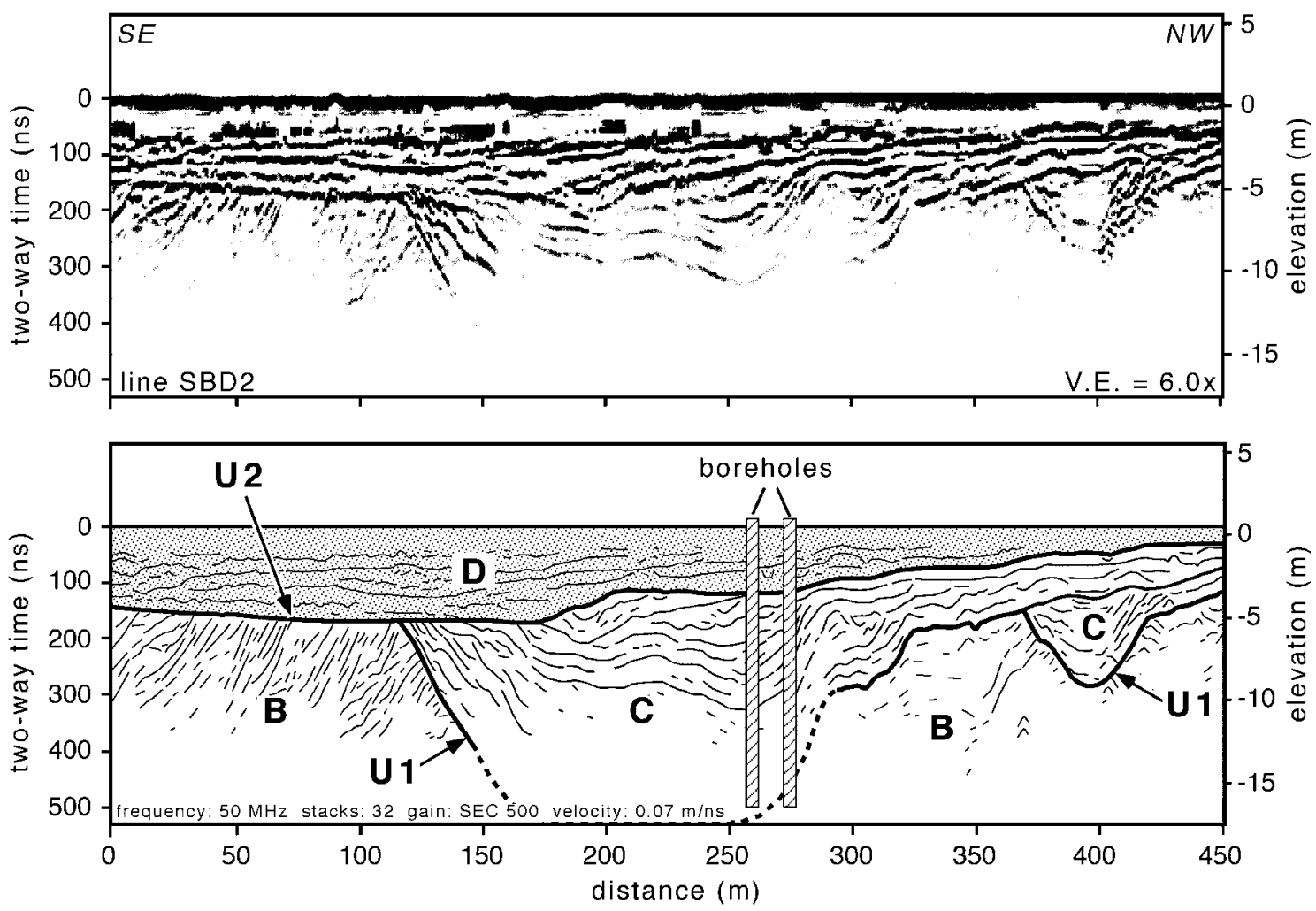

Figure 7. Interpreted GPR profile along beach at base of landslide scarp. Channel deposits of unit C are stacked and record a general west to east migration with deepening. It is uncertain if the boreholes penetrated the base of the paleochannel deposits (unit C). See text for description of units. Location indicated in Figures 1 and 4B.

thickness from 2-8 m (Figures 7 and 8). Internal reflections are laterally continuous and flat-lying to gently dipping. The upper boundary of unit D locally crops out on the ground surface and is characterized by numerous, well rounded clasts of pebble to cobble size. In many areas, large dunes overlie unit $\mathrm{D}$. It is unclear if unit $\mathrm{D}$ extends beneath the entire dune, rather it may pinch out laterally and unit A may form the core of the dune (Figure 6). We interpret unit D to represent beach and nearshore deposits of middle to late Holocene age, a time period that begins with the Nipissing Phase $+7 \mathrm{~m}$ highstand and includes the ensuing regression. By this interpretation, Unit D represents a sandy, nearshore facies that is correlative with unit Qlu. Similarly stratified, near-shore sand deposits also formed in southern Lake Michigan during highstand conditions (THOMPSON, 1990).

Unit $\mathbf{E}$ is always the uppermost stratigraphic unit, where present, and unconformably overlies units D and A (Figures 6 and 8 ). Unit $\mathrm{E}$ is internally well stratified, and locally exhibits 5-m thick packets of prograding clinoforms that generally dip to the southeast at angles of 15-25 degrees. Avalanche beds of similar scale and orientation are exposed in outcrop along the landslide scarp. A high-amplitude, continuous reflection marks the base of unit E, which is up to 25 $\mathrm{m}$ thick. Unit $\mathrm{E}$ represents eolian deposits or sand dunes, some rising up to $136 \mathrm{~m}$ above lake level in the SBDNL.

\section{BOUNDING SURFACES}

This study uses a sequence-stratigraphic approach to define units largely on the basis of their bounding surfaces, usually unconformities that represent significant periods of erosion or non-deposition. Changes in sediment texture and/or composition typically occur at unconformable contacts and produce distinct reflections on seismic reflection and GPR records. This study recognizes three major unconformities as important sequence boundaries.

The first unconformity (U1) is marked by a prominent reflection at the base of unit $\mathrm{C}$, the paleochannel deposits, and exhibits cross-cutting relationships with the internal reflections of unit B (Figures 7 and 8). We interpret unconformity U1 as the basal unconformity that formed when lake level fell to about $80 \mathrm{~m}$ below the present shoreline approximately 10.3 ka B.P. (Colman et al., 1994; Figure 3A). This regressive surface was only observed in GPR profiles onshore. The offshore equivalent of unconformity U1 was probably eroded during the lake-level rise that followed the lowstand.

The second unconformity (U2) is marked by a laterally continuous, well-defined reflection that was observed on seismic reflection data offshore and on GPR data onshore. In offshore areas, the U2 unconformity forms the base of unit Qlu, which is buried by $5-25 \mathrm{~m}$ of younger material, and extends down 

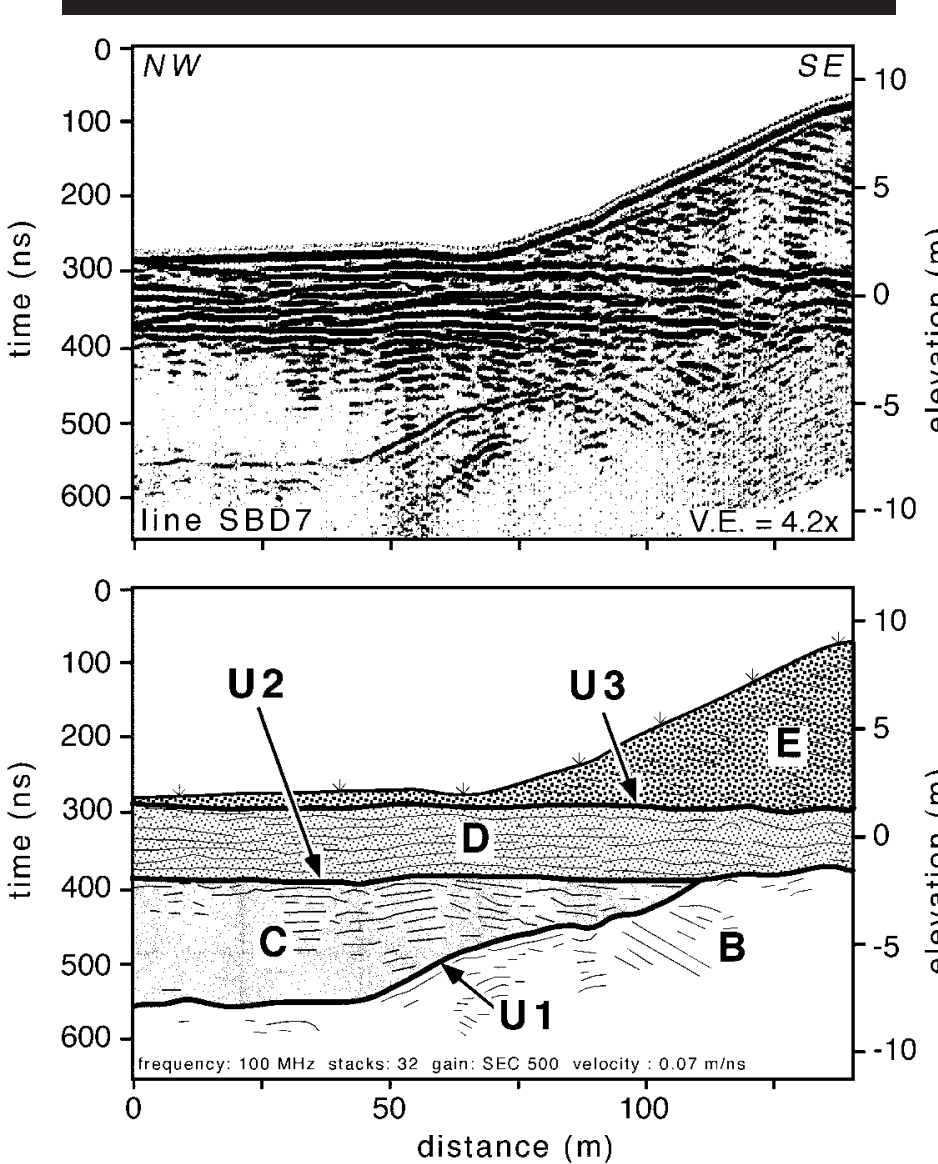

Figure 8. Interpreted GPR profile showing complete stratigraphy of coastal bluff. Location is adjacent to landslide zone, as indicated in Figure $4 \mathrm{~B}$

the basin slope to depths of at least $80 \mathrm{~m}$ below present lake level (Figure 5). Cores in southern Lake Michigan penetrated an equivalent surface (reflector R2 of FOsTER and COLMAN, 1991; Chippewa unconformity of Colman et al., 1994) and contained a sandy, shelly layer that separated underlying reddish glaciolacustrine mud from gray lacustrine mud above. Onshore, unconformity $\mathrm{U} 2$ forms the base of unit $\mathrm{D}$, and truncates the dipping strata of units $\mathrm{B}$ and $\mathrm{C}$, forming well-defined angular unconformities (Figures 7 and 8). Boreholes onshore penetrated this unconformity but contained no evidence of lithologic changes that were observed offshore. Well-sorted sand occurred just above and just below the expected depth of the reflection. We interpret the U2 surface as a time-transgressive, shoreface ravinement unconformity (e.g., SwIFT, 1968), an erosional surface that formed by wave erosion as lake level rose from the Chippewa Phase lowstand to the Nipissing highstand in the middle Holocene.

The third unconformity (U3) is a smooth, planar, highly reflective surface that marks the top of unit D (Figures 6 and 8 ), and was observed only with GPR profiles in the vicinity of Sleeping Bear Point. The U3 contact is overlain by deposits of unit $\mathrm{E}$ that are up to $30 \mathrm{~m}$ thick. No boreholes penetrated the U3 contact, but a lag deposit of gravel was observed in several locations where it crops out on the surface. We interpret U3 to represent an erosional unconformity that formed as the lake fell from the Nipissing highstand to the modern level.

\section{LAKE-LEVEL CHANGE AND COASTAL EVOLUTION}

Lake-level change has been one of the most important geomorphic and stratigraphic agents acting on the coast of Lake Michigan during the Holocene. Changes in relative lake level, which includes both the actual level of water in the basin and isostatic movements of the land, have caused multiple regressions and transgressions of the shoreline. These shoreline migrations extensively reworked the coastal zone and nearshore areas, and created widespread unconformities. The unconformities separate and largely define the ten stratigraphic units observed in this study. Geomorphic and stratigraphic relationships among these units (Figure 9) form the basis of a conceptual model of coastal evolution at SBDNL.

The model begins about $10.3 \mathrm{ka}$ B.P. with the large-scale regression to the Chippewa phase lowstand. Lake level rapidly fell to a depth of about $80 \mathrm{~m}$ below present and exposed shallow parts of the lake floor to subaerial erosion. Streams incised unit B and etched the basal unconformity U1 on the surface of older glacial sediment. Eroded sediment was transported into deeper parts of the basin, but no submerged deltas or shoreline features were observed on the lake floor at SBDNL or other parts of Lake Michigan (Foster and CoLMAN, 1991, 1992). Abundant wind-blown sand, derived from exposed parts of the lake floor, probably favored the growth of dunes during regression and lowstand.

The lowstand was short lived and was followed by about 5,000 years of lake-level rise. Channel-fill material of unit $\mathrm{C}$ accumulated as the rising lake submerged the stream channels. Emergent areas along the coast experienced a second episode of erosion as the transgressive shoreface again reworked nearshore areas, probably eroding most regressive and lowstand deposits. The U2 unconformity, equivalent to the R2 reflector of Foster and CoLMAN (1991, 1992), was etched into the top of older deposits. Most of unconformity U1, where it occurred in the shallow subsurface, was eroded during the transgression. Remnants of unconformity U1 are only preserved at the base of paleochannels. Preservation was possible because the sub-bottom depth of regressive unconformity U1 was greater than the depth of shoreface erosion that formed transgressive unconformity U2 (e.g., BELKNAP and KRAFT, 1985).

The lake progressively inundated the coast until about 4.7 ka B.P., when it reached the Nipissing highstand at $7 \mathrm{~m}$ above present lake level. Coastal erosion increased during the highstand, which lasted several thousand years, and formed a wave-cut terrace at the tip of Sleeping Bear Point (Figure 4B). The flat terrace is etched into glacial and lacustrine sediment, forming unconformity U2, and largely buried with beach deposits and sand dunes (Figure 8). Coastal bluffs probably retreated a significant but unknown distance during this time, and supplied sediment to the littoral zone. Glen Lake is a small inland basin that was probably connected to 


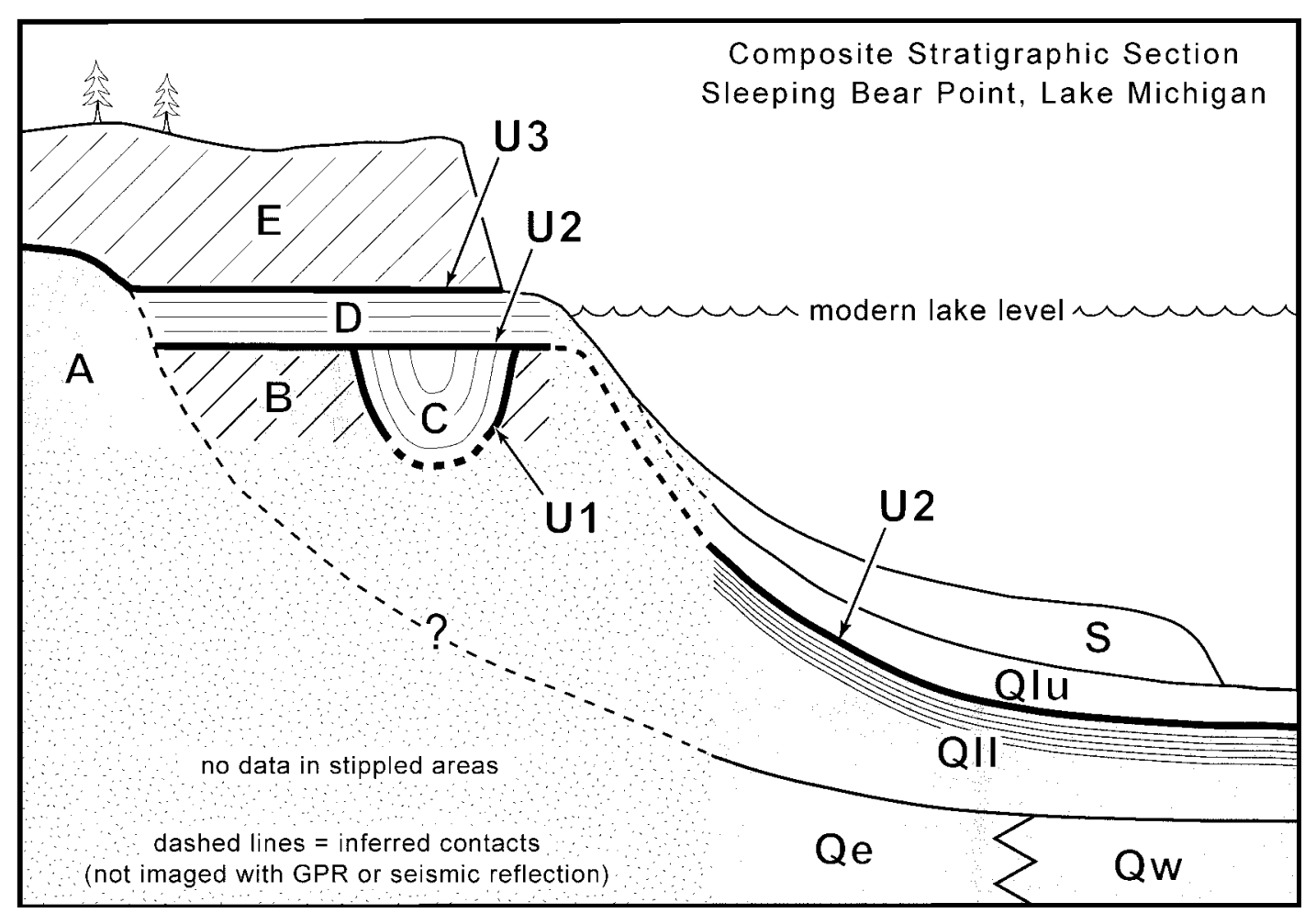

Figure 9. Schematic diagram of landslide zone at Sleeping Bear Point, depicting 10 stratigraphic units and three prominent unconformities imaged by seismic reflection (offshore) and GPR (onshore). Note that actual orientation of the paleochannel (unit C) is perpendicular to the shoreline. Darker shading indicates late Pleistocene deposits; lighter shading indicates Holocene deposits. Figure not drawn to scale.

Lake Michigan during the highstand (Figure 10). The buried channels may represent an old outlet that was subsequently abandoned.

Relative lake level has fallen approximately $7 \mathrm{~m}$ since the middle Holocene, exposing shallow nearshore areas and forming the regressive unconformity U3 (Figure 9). Emergent lake terraces with wide beaches supplied abundant eolian sediment, and probably enhanced the downwind growth of coastal dunes. Radiocarbon dating of soils beneath dunes suggests, however, that increases in lake level destabilized coastal bluffs and triggered dune construction along the eastern shore of Lake Michigan (ARBogast and Loope, 1999). Whichever is true, large sand dunes are actively migrating in the vicinity of Sleeping Bear Point and have buried unconformity U3 with about $30 \mathrm{~m}$ of sand. This thick section of loosely consolidated sediment is susceptible to landslides and large sections have failed in historic time. High sediment supply and fluctuating lake levels have formed a series of beach ridges that separate Glen Lake from Lake Michigan (Figure 2). The paleochannels beneath Sleeping Bear Point suggest that the formation of dunes and beach ridges sealed off a former outlet of Glen Lake (Figure 10), which presently lies about $5 \mathrm{~m}$ above the level of Lake Michigan.

\section{CONCLUSIONS}

The late Quaternary stratigraphy of SBDNL preserves a record of profound changes in the level of Lake Michigan.
Sequence-stratigraphic analysis of onshore and offshore deposits, and the unconformities that bound them, indicate two periods of lake-level fall separated by a lake-level rise. A stacked pair of stream channels, probably former outlets of Glen Lake, were incised into the lake floor during one or more lowstands, and filled with sediment during the early Holocene transgression. The channel-fill and other lacustrine deposits were truncated as lake level rose from a depth of about $80 \mathrm{~m}$ below to about $8 \mathrm{~m}$ above the present shoreline. Unconformity U2 is a time-transgressive surface that formed during this period of lake-level rise and is the most prominent stratigraphic feature in the subsurface. The regressive unconformity U1 is preserved only at the base of the paleochannels, where it is buried by thick deposits of channel-fill, dune, and beach sediment. No lowstand features (i.e., submerged shorelines) were observed in offshore areas.

The thick section of postglacial sediment at SBDNL is prone to large-scale, episodic failures. A landslide in 1995 covered approximately $20 \mathrm{~km}^{2}$ of lake floor with an estimated one million $\mathrm{m}^{3}$ of debris. Assessments of landslide hazards are typically based on topographic surveys, outcrop observations, and widely spaced boreholes, and often conclude that the bluffs most likely to fail are steep and unconsolidated. Those criteria fit much of the coastline of Lake Michigan and offer little guidance for precisely locating hazardous areas and minimizing risks. Although it may be costly, a detailed examination of subsurface geology is necessary to identify 


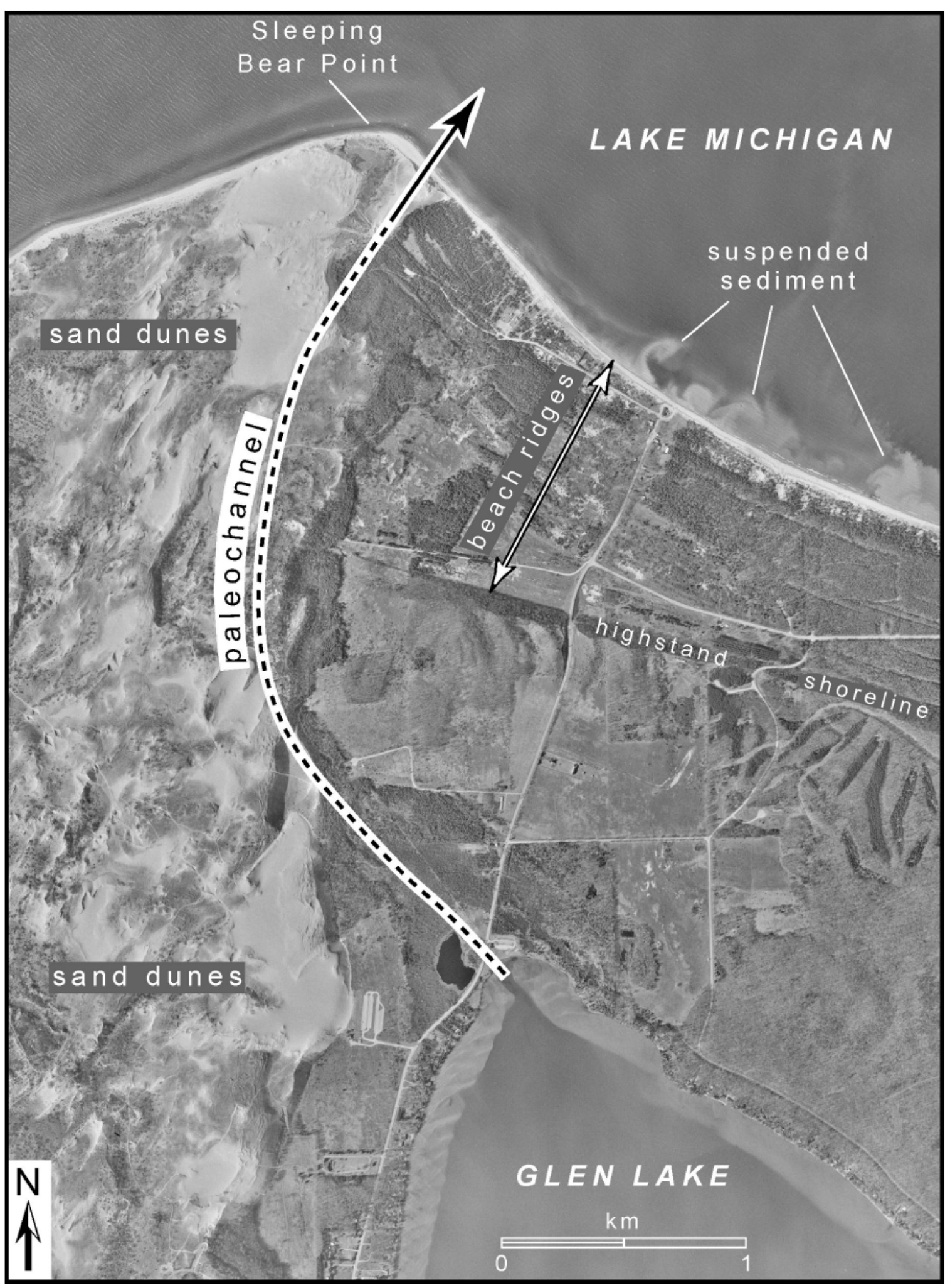

Figure 10. Air photo of study area in 1993. The paleochannel is inferred to connect Glen Lake with Lake Michigan; location is approximate. Location indicated in Figure 2. 
anomalous conditions that control the distribution of landslides and degree of mass-movement activity. Buried channel deposits were observed only in the area of active landsliding and may act as a conduit for pore water flow from Glen Lake to Lake Michigan. Groundwater piping through such a conduit may locally reduce soil strength and cause slope instability. There are no data to confirm this, but locally increased pore-water pressures in the active landslide zone may have important implications for the interaction of groundwater and surface-water systems.

\section{ACKNOWLEDGEMENTS}

Generous support for this project was provided by Max Holden and Steve Yancho of Sleeping Bear Dunes National Lakeshore. We thank the captain and able crew of the $R / V$ Neptune, and Les Davis of Sensors and Software, Inc. Mike Boyle, Tom Reiss, B.J. Reynolds, and Brian Bangma helped with the field work. This manuscript benefited from reviews by David Foster, Wayne Newell, Mike Chrzastowski, and Todd Thompson.

\section{LITERATURE CITED}

Arbogast, A.F. and Loope, W.L., 1999. Maximum-Limiting Ages of Lake Michigan Coastal Dunes: Their Correlation With Holocene Lake Level History. Journal Great Lakes Research, 25, 372-382.

BAEDKe, S.J. and Thompson, T.A., 2000. Deriving an single record of lake level and isostasy for Lake Michigan from four relative lake-level curves. Geological Society of America Abstracts with Programs, 33(4), 11.

BELKNAP, D.F. and KrafT, J.C., 1985. Influence of antecedent geology on the stratigraphic preservation potential and evolution of Delaware's barrier systems. Marine Geology, 63, 235-262.

Beres, M. and HaEnI, F.P., 1991. Application of ground-penetrating-radar methods in hydrogeologic studies. Groundwater, 29, 375386.

Chrzastowski, M.J. and Thompson, T.A., 1992. Late Wisconsinan and Holocene coastal evolution of the southern shore of Lake Michigan, In: Fletcher, C.H. and WeHMiLler, J.F. (eds.), Quaternary Coasts of the United States: Marine and Lacustrine Systems, SEPM Special Publication No. 48, pp. 397-413.

Colman, S.M.; Jones, G.A.; Forester, R.M., and Foster, D.S., 1990. Holocene paleoclimatic evidence and sedimentation rates from a core in southwestern Lake Michigan. Journal of Paleolimnology, 4, 269-284.

Colman, S.M.; Forester, R.M.; Reynolds, R.L.; SweetKind, D.S.; King, J.W.; Gangemi, P.; Jones, G.A.; Keigwin, L.D., and FosTER, D.S., 1994. Lake-level history of Lake Michigan for the past 12,000 years: The record from deep lacustrine sediments. Journal of Great Lakes Research, 20(1), 73-92.

DorR, J.A., JR. and Eschman, D.F., 1970. Geology of Michigan: University of Michigan Press, Ann Arbor, Michigan, 476p.

DotT, E.R. and Mickelson, D., 1995. Lake Michigan water levels and the development of Holocene beach-ridge complexes at Two Rivers, Wisconsin: Stratigraphic, geomorphic, and radiocarbon evidence. Geological Society of America Bulletin, 107(3), 286-296.

Foster, D.S. and Colman, S.M., 1991. Preliminary interpretation of the high-resolution seismic stratigraphy beneath lake Michigan. U.S. Geological Survey Open-File Report 91-21, 42 p.

Foster, D.S. and Colman, S.M., 1992. Maps and seismic profiles showing thickness and distribution of postglacial deposits beneath the southern two-thirds of Lake Michigan. U.S. Geological Survey Misc. Investigations Map I-2202, scale 1:500,000.
Fraser, G.S.; Larsen, C.E., and Hester, N.C., 1990. Climatic control of lake levels in the Lake Michigan and Lake Huron basins, In: SCHNEIDER, A.F. and Fraser, G.S. (eds.), Late Quaternary History of the Lake Michigan Basin, Geological Society of America Special Paper 251, p. 75-89.

HaNDS, E.B., 1979. The Great Lakes as a test model for profile responses to sea-level changes, In: Komar, P.D. (ed.), CRC Handbook of Coastal Processes and Erosion, CRC Press, Boca Raton, Florida, pp. 167-189.

HANSEL, A.K. and Mickelson, D.M., 1988. A reevaluation of the timing and causes of high lake phases in the Lake Michigan basin. Quaternary Research, 29, 113-128.

Hansel, A.K.; Mickelson, D.M.; Schneider, A.F., and Larsen, C.E., 1985. Late Wisconsinan and Holocene history of the Lake Michigan basin In: KarRow, P.F. and CALKIN, P.E. (eds.), Quaternary Evolution of the Great Lakes, Geological Association of Canada Special Paper 30, pp. 39-53.

Hough, J.L., 1958. Geology of the Great Lakes. Urbana, Illinois: University of Illinois Press, 313p.

KNEBEL, H.J. and ScanlON, K.M., 1985. Sedimentary framework of Penobscot Bay, Maine. Marine Geology, 65, 305-324.

LARSEN, C.E., 1985. Lake level, uplift, and outlet incision; The Nipissing and Algoma Great lakes In: KARROw, P.F. and CALKIN, P.E. (eds.), Quaternary Evolution of the Great Lakes, Geological Association of Canada Special Paper 30, pp. 63-77.

LichteR, J., 1995. Lake Michigan beach-ridge and dune development, lake level, and variability in regional water balance. Quaternary Research, 44, 181-189.

LineBACK, J.A.; AyER, N.J., and Gross, D.L., 1970. Stratigraphy of unconsolidated sediments in the southern part of Lake Michigan. Illinois State Geological Survey, Environmental Geology Note No. 35,35 p.

Mullins, H. T. and Hinchey, E.J., 1989. Erosion and infill of New York Finger Lakes: implications for Laurentide ice sheet deglaciation. Geology, 17, 622-625.

National Buoy Data Center, 1999. North Michigan station information 45002: National Oceanic Atmospheric Administration (NOAA), http://seaboard.ndbc.noaa.gov.

National OCEANic Atmospheric Administration (NOAA), 1971. Bathymetric map no. I-2304: National Ocean Survey (NOS), Lake Survey Section, scale 1:250,000, sheet 1 of 2.

Posamentier, H.W. and Vail, P.R., 1988. Eustatic controls on clastic deposition II-sequence and systems tract models In: WILGUS, C.K.; Hastings, B.S.; Kendall, C.G.; Posamentier, H.W.; Ross, C.A., and von WAGONER, J.C. (eds.), Sea-level changes-an integrated approach, SEPM Special Publication 42, pp. 125-154.

SMitH, D.G. and Jol, H.M., 1995. Ground penetrating radar: Antenna frequencies and maximum probable depths of penetration in Quaternary sediments. Journal of Applied Geophysics, 33, 93100.

Sommers, L.M. (ed.), 1977. Atlas of Michigan. East Lansing, Michigan: Michigan State University Press, 242p.

SwIFT, D.J.P., 1968. Coastal erosion and transgressive stratigraphy. Journal of Geology, 76, 444-456.

Thompson, T.A., 1990. Dune and beach complex and back-barrier sediments along the southeastern shore of Lake Michigan; Cowles Bog area of the Indiana Dunes National Lakeshore, In: ScHNEIDER, A.F. and FrASER, G.S. (eds.), Late Quaternary History of the Lake Michigan Basin, Geological Society of America Special Paper 251 , pp. 9-19.

Thompson, T.A. and BAEdKe, S.J., 1997. Strand-plain evidence for late Holocene lake-level variations in Lake Michigan. Geological Society of America Bulletin, 109(6), 666-682.

VAil, P.R.; Mitchum, R.M.; JR., TodD, R.G.; Widmier, J.M.; Thompson, S.; III, SANGRee, J.B.; BubB, J.N., and Hatelid, W.G., 1977. Seismic stratigraphy and global changes in sea level In:PAYTon, C.E. (ed.), Seismic Stratigraphy-Applications to Hydrocarbon Exploration, AAPG Memoir 26, pp. 49-212. 